\title{
Perception of the reasons for living in poverty in Hungary
}

\author{
Eszter Siposné Nándori*
}

University of Miskolc, Miskolc, Hungary

\section{ORIGINAL RESEARCH PAPER}

Received: April 22, 2021 • Accepted: September 20, 2021

Published online: November 10, 2021

(c) 2021 The Author(s)

\begin{abstract}
The question of what are considered the causes of poverty is often neglected in the literature of this area of research. This paper analyzes the attributes of poverty in Borsod-Abaúj-Zemplén County, Hungary, which is one of the most disadvantaged areas of the country. Research was carried out in 2011 and 2019 using the method of systematic data collection, making possible the comparison of the changing perceptions of poverty over time. The research objective is to discover whether, as is common in Eastern European countries, support for explanations which blame structural conditions is dominant in the public perception of poverty. This research has made it clear, that the poor are often considered by the public to be responsible for their own vulnerable situation. With regard to the area where the research took place there is a discrepancy between reality and the public perception of poverty and the functioning of the welfare system which is thought to be generous and which is considered to offer multiple types of public aid for a wide range of recipients.
\end{abstract}

\section{KEYWORDS}

perception of poverty, cause of poverty, systematic data collection, Hungary, cultural competence, consensus theory

\section{INTRODUCTION}

A number of studies in this field of research (such as Coughlin 1980; Taylor-Gooby 1985; TylorGooby and Svallfors 1999) have examined attitudes towards the welfare system, the role of

\footnotetext{
*Corresponding author. E-mail: stsne@uni-miskolc.hu
} 
government in the alleviation of poverty, the legitimacy of the welfare state, tax progression, and income redistribution. In the field of social policy, however, less attention has been paid to public perceptions of poverty, notwithstanding that over a hundred years ago Simmel (1908) argued that popular beliefs about poverty may have an important impact on welfare regimes. Beyond its relevance to social policy, attributions of poverty play an important role in sociology and in economics, as well. The redistribution of income must be justified in order for it to gain social acceptance, which in turn is necessary to ensure the sustainable functioning of the welfare system. It is not enough to simply launch a concept of the welfare system; this concept must also be morally and ethically justified. The legitimacy and viability of welfare programs are significantly influenced by public perceptions of poverty (Lepianka et al. 2009; van Oorschot and Halman 2000). Support for structural attributions of poverty may encourage public acceptance of the social welfare programs (Habibov 2011; Verwiebe and Wegener 2000). Moreover, lay explanations of poverty reveal important aspects of the existing welfare culture, as well as the moral economy of society by providing information about the status of a given social group (Mau 2003; Pfau-Effinger 2005). In addition, perceptions of poverty influence interactions between poor and non-poor communities on a daily basis (Bullock 1999; Niemela 2008; Siposné Nándori 2021).

This paper examines the perception of the underlying reasons for living in poverty in Hungary. It focuses on Borsod-Abaúj-Zemplén County, which has been one of the poorest areas in Hungary for decades. The reason for selecting this county was, that a relatively large proportion of its population lives in poverty or experiences poverty in their immediate surroundings. The latter is important too, as the perception of those living physically close to poverty are of particular interest. Attributions of poverty were examined in 2011 and 2019 using the methods of systematic data collection, making possible the comparison of the results over time.

The paper differs from the existing literature in several aspects. Besides focusing on a county in Hungary, another unique trait of the current research lies in its methodology. As mentioned earlier, the research which this paper is based on relies on the method of systematic data collection to obtain information about subjective poverty. This use of systematic data collection can improve the quality of data while significantly reducing the required sample size. Moreover, and most importantly, these methods do not use predefined attributions of poverty scaling like many other previous studies in the field have done, ${ }^{1}$ but participants are first asked to elicit items they have in their minds about poverty and these same items are then used for the subsequent steps of the research.

The first step towards understanding the problem is to describe the theories regarding the attributions of poverty, with special regard for lay explanations of poverty in Eastern Europe. A review of the socioeconomic conditions of Borsod-Abaúj-Zemplén County, Hungary, is then presented. After stating the research objectives, the study briefly describes its methodology. The main findings of primary data collection, and the results of analysis are described in the Results section.

\section{ATTRIBUTIONS OF POVERTY}

The first research work on the public opinions and beliefs about the causes of poverty was published more than half a century ago. Free and Cantril (1967) recognized that individualistic

${ }^{1}$ Like Kluegel and Smith (1981), Kluegel and Smith (1986) or Feather (1974). 
traits like hard work or willpower were thought to predominate "success" more than "circumstantial" factors in the United States. Feagin (1975) revealed that three categories of causes can be distinguished in the United States:

- individualists (when poverty is related to the attitude of the individual);

- structuralists (the causes of poverty are related to the society);

- fatalists (when individuals get into poverty randomly or due to fate) (Harper 1996).

Besides these factors, attributions of poverty have been associated with financial circumstance (Williamson 1974) and ethnicity (Hunt 1996). Feagin (1975) concluded that most Americans believed that the individual was responsible for being poor, which is in in line with the individualistic theory. Other research (Kluegel and Smith 1981, 1986) used the same set of items as Feagin and revealed that individualistic beliefs continued to predominate the public perception of poverty in the United States in the 1980s and 1990s (Wilson 1996; Hunt and Bullock 2016). Smith and Stone (1989) also confirmed that the main perceived causes of poverty in America are either individualistic or structural. Zucker and Weiner (1993) used the theory of attribution to examine the causal explanations of poverty and categorized the causes into the same three types as Feagin.

It was Furnham (1982) who recognized that previous studies regarding the attributions of poverty included an individualistic type of blame (such as low willingness to work or lack of proper money management by the poor), as well as a social type of blame (like the lack of real social safety nets), and an individual type of fate (like bad luck), but not a social type of fate. He identified this type of explanation for poverty and included factors like worldwide recession or uncontrollable global development. Van Oorschot and Halman (2000) suggested a twodimensional and four-type poverty explanation model (Fig. 1). Lepianka et al. (2009) and Kainu and Niemelä (2014) confirmed the four-tiered structure of poverty attributions.

Lepianka et al. (2009) provided a critical view of the two most common approaches of analyzing attributions of poverty: the factor analytical approach and the forced-choice-question approach. Eurobarometer, among others, has used the latter method. They concluded that neither of these approaches were faultless from a methodological point of view, thus necessitating the development of better tools for measuring the attributions of poverty. The use of a longer list of items was suggested, as well as reference to some sort of additional information from the interviewees about their images of the poor in order to elucidate the interpretation of the survey items, or using alternative approaches to study causal interpretations.

Besides Simmel (1908), Kluegel et al. (1995) and Jordan (1996) argued that the percieved generosity of the welfare system was directly dependent on the degree to which the poor were seen by the public as being personally responsible for their vulnerable situation. Since the early 1970s the development of universal welfare states in continental Europe have been associated with structural explanations for poverty which support the need for a welfare state and for other initiatives aimed at reducing poverty (Kluegel et al. 1995). In line with this finding, there is wide consensus to support structural explanations of poverty (such as social injustice or problems regarding the labor market) in Finland (Niemelä 2008). In Angol-Saxon tradition, however, development of the residual welfare state has been associated with the increasing importance of individualistic and fatalistic attributions of poverty (Hartz 1995; Habibov et al. 2017). Individualistic explanations undermine collective actions to fight against poverty and inequalities (Kreidl 1998, 2000; Habibov 2011). 


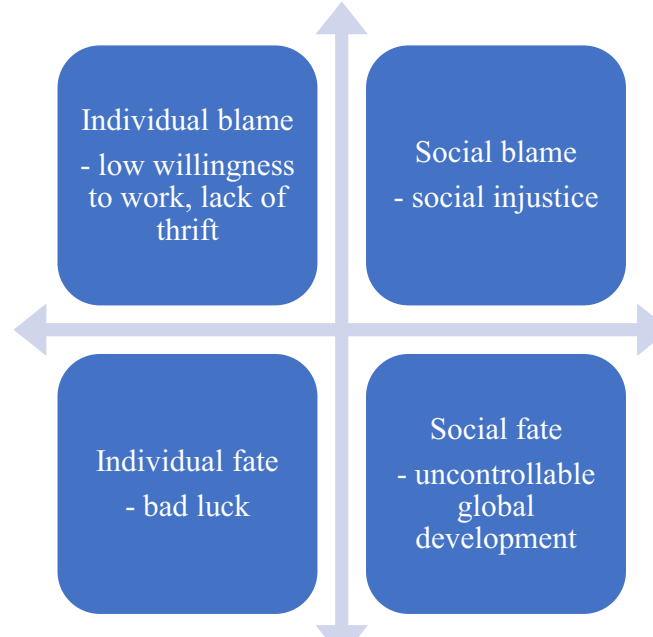

Fig. 1. Two dimensions and four types of poverty explanations

Source: own compilation based on Van Oorschot and Halman $(2000$, p. 7$)$

Beyond the characteristics of the welfare system, short-term economic growth, social expenditures, demographic factors, and political affiliation are among the determinants of attributions of poverty in Europe, creating differences in the explanations of poverty across European countries (Kallio and Niemelä 2014).

Hughes and Touch (2000), Hunt (1996), Kluegel and Smith (1986), Lee et al. (1990), and Merolla et al. (2011) showed that individualistic and structural explanations for poverty are not mutually exclusive, but are instead overlapping constructs. Disadvantaged strata like the working class, homeless people, or racial minority groups are likely to combine individualistic and structural beliefs in their thinking (Cheal 1979; Kluegel et al. 1995; Kluegel and Smith 1986; Parkin 1971). Merolla et al. (2011), using data from the United States, found that 'concentrated disadvantage' at community level was associated with support for both individualistic and structural attributions of poverty resulting in a 'dual consciousness' pattern.

Kluegel and Smith (1986) argued that structural beliefs might temporarily become dominant during times of unusual social and/or economic strain. Marquis (2020) confirmed that following the 2008 economic crisis, support for explanations which blame structural conditions had increased in Europe.

\section{LAY EXPLANATIONS OF POVERTY IN POST-SOCIALIST COUNTRIES, ESPECIALLY IN HUNGARY}

Empirical findings on the attributions of poverty found that there were some differences between Western Europe and post-socialist Europe (Kainu and Niemelä 2014). While social explanations for poverty are more popular in Western Europe, Eastern Europeans emphasize more 
individualistic reasons of blame for poverty (Kallio and Niemelä 2014; Kreidl 2000; Lepianka et al. 2009; van Oorschot and Halman 2000). Lepianka et al. (2009) concluded, however, that large variations could be found across post-socialist European countries. Individualistic types of blame for explaining poverty are more popular in the Czech Republic, while the social type of blame for the attributions of poverty are endorsed in Lithuania, Poland, Romania, and Croatia (Lepianka et al. 2009). Kainu and Niemelä (2014) concluded that in post-socialist countries, social types of blame for explaining poverty are the most popular, followed by individualistic types of blame, social fate, and individual fate. Another finding of their research showed that social types of blame for explaining poverty are the most popular in Ukraine, Lithuania, Slovenia, Hungary, Russia, and Latvia.

Few studies regarding lay explanations of poverty have focused specifically on Hungary. Kreidl (2000) revealed that there was no dominant ideology for poverty in Hungary in the 1990s. In 1991 and 1996, 75\% of his respondents chose the failing economic system and $71 \%$ chose poor morals as explanations for poverty in Hungary. Habibov et al. (2017), concluded, by examining 24 post-communist countries using a total sample of 37,307 respondents, that structural attributions of poverty were supported by more than half of the respondents in Hungary between 2006 and 2010, and support for structural explanations for poverty had increased over time from 54.8\% in 2006 to 59.8\% (the third highest rate out of the eight Eastern European countries examined) in 2010.

\section{SOCIOECONOMIC POSITION OF BORSOD-ABAÚJ-ZEMPLÉN COUNTY, HUNGARY}

Similarly to other post-socialist countries, the transition period of 1989-1990 was characterized by a rapid increase in the regionalization of wealth and deprivation. The increase of regional disparities was associated with the increasing dominance of Budapest, the capital city, as well as the widening gap between urban and rural areas, and the declining economic performance of the old industrial regions (Blazek and Netrdová 2011; Keller et al. 2016) such as Northern Hungary. Due to deindustrialization, which began in the early 1990s, industrial activities in Borsod-AbaújZemplén County, situated in Northern Hungary, significantly decreased and the number of jobs fell significantly. The two main metallurgic companies went bankrupt and closed, resulting in a regional crisis. In this area the 1990s were characterized by a distorted economic structure, underdeveloped infrastructure, failed privatization, several thousands of unemployed people, and large-scale emigration (Bakos 2006). It was only after the turn of the century that industry in Northern Hungary began to develop and catch up to the more developed Central and Western parts of the country. Re-industrialization started only after 2003 and it lead to economic structural changes. Investments have lately been concentrated in the industrial and energy sectors (Barta et al. 2008).

To this day, Borsod-Abaúj-Zemplén County is characterized by unemployment and poverty (Keller et al. 2016) as well as a low ability to retain its population. This is due to the lack of viable economic prospects and the adverse income position of the inhabitants (G Fekete et al. 2013). Emigration per capita was the highest of all seven NUTS2 level regions of the country in Northern Hungary. Seven out of one thousand inhabitants left the country in 2010. Most people leaving Borsod-Abaúj-Zemplén County move to Central Hungary (Grábics 2012). 
The unfavorable socioeconomic situation of the county is reflected by the high percentage of ethnic Roma people with a low level of education, a low rate of participation in the labor market, and a high level of experience of social discrimination (Hegyi-Kéri and Horváth 2017). Roma people form the largest and most disadvantaged ethnic minority in Hungary. Identifying who belongs to the Roma minority is not easy because the definition of Roma is a contentious subject. According to the latest, 2011 census, where self-declaration of belonging to any ethnic minority was possible, the Roma minority comprised $3.18 \%$ of the total population, while various sociological studies estimate this number to be as high as $8-10 \%$ of a total population of 9.8 million (Kimmelman 2008). Their territorial distribution is uneven, with highest concentration in the north-eastern and in the south-western parts of the country. One of the highest concentrations of Roma people can be found in Borsod-Abaúj-Zemplén County where close to $10 \%$ of the total population called themselves Romani in the 2011 census.

Roma people experience multiple disadvantages. Besides living in relatively poor regions, they experience low levels of education and employment, as well as poor living conditions. It is often difficult to measure their socio-economic characteristics because data is usually not selected and gathered based on ethnicity. In addition to their unfavorable socioeconomic position, their life expectancy is approximately ten years lower than that of the non-Roma population. They often experience poor levels of hygiene and sanitation and have relatively high rates of infectious disease (Masseria et al. 2010). Moreover, they face environmental problems like the lack of sewage and mains gas, garbage dumps, waterlogged soil, and lack of running water (Kósa et al. 2009).

Besides being disadvantaged for multiple reasons, Roma people have experienced problems regarding integration. They have been subject to discrimination by much of society, probably due to their traditionally nomadic lifestyle, tightly knit communities, and distinct culture (Kósa et al. 2009). A further characteristic of their issues surrounding integration is that after completing primary education, only one in five Romani children go on to secondary education. The drop-out rate among Romani children is almost twice as high as among non-Romani. A further problem is the segregation of Romani children to separate schools or classes due to non-Romani families choosing to send their children to distant schools when there are many Romani students in the local schools (this phenomenon is often called "white flight") (Open Society Institute 2007). Beyond the above, the difficulty of their integration into society is exacerbated by the negative attitudes towards them as a result of racist stereotypes including the idea that they are disproportionately dependent on the welfare system, they lack work discipline, they are the primary perpetrators of various types of crimes, and do not respect legal and social norms (Csepeli and Simon 2004; Babourkova 2016).

To make existing conditions worse, several violent events occurred between the non-Roma and Romani people which highlighted and aggravated the issues surrounding their integration. One such example is an incident dating back to 2006 when a Roma mob lynched an ethnic Hungarian teacher in front of his two daughters in the village of Olaszliszka, Borsod-AbaújZemplén County. The incident was then followed by many racially motivated attacks against Roma people (Index 2006).

\section{HYPOTHESES AND METHODOLOGY}

This study aims to discover lay explanations of poverty in a disadvantaged area of Hungary. Considering the research results of Kainu and Niemelä (2014), and Habibov et al. (2017), for 
other Eastern European countries, support for explanations which blame structural conditions can be dominant in the public perception of poverty.

Figure 2 highlights the main steps of the research process upon which this study is based. Primary data collection was carried out following a review of the relevant literature and the formulation of hypotheses. Subjective interpretations of poverty, and the items related to it were identified using qualitative research methods. Interviews were conducted first, to elicit a list of items related to poverty using the method of free listing. Besides these related items, the main causes and consequences of poverty were also identified. The method of free listing is an appropriate way to ensure that the domain and the items are culturally relevant (Weller and Romney 1988; Siposné Nándori 2021).

In a subsequent session of interviews, participants were asked to rank the items related to poverty, as well as the causes of poverty, and consequences of poverty according to how strongly they are linked to poverty. It is important to use the same items which were first identified in the process of free listing. Responses to the questions of the free listing cannot be corrected, recoded or transformed (Weller 2007) to facilitate the interpretation of the survey items (Lepianka et al. 2009) in the second part of the interviews.

During the second phase of research, participants were asked to describe the exact meaning of the previously identified items. As ranking a large number of items could be difficult and could take considerable time, the method of systematic data collection was used to simplify the task, thereby eliminating time-on-task cognitive fatigue. Another reason for applying this method was that it made possible the comparison of results of two time periods, provided that

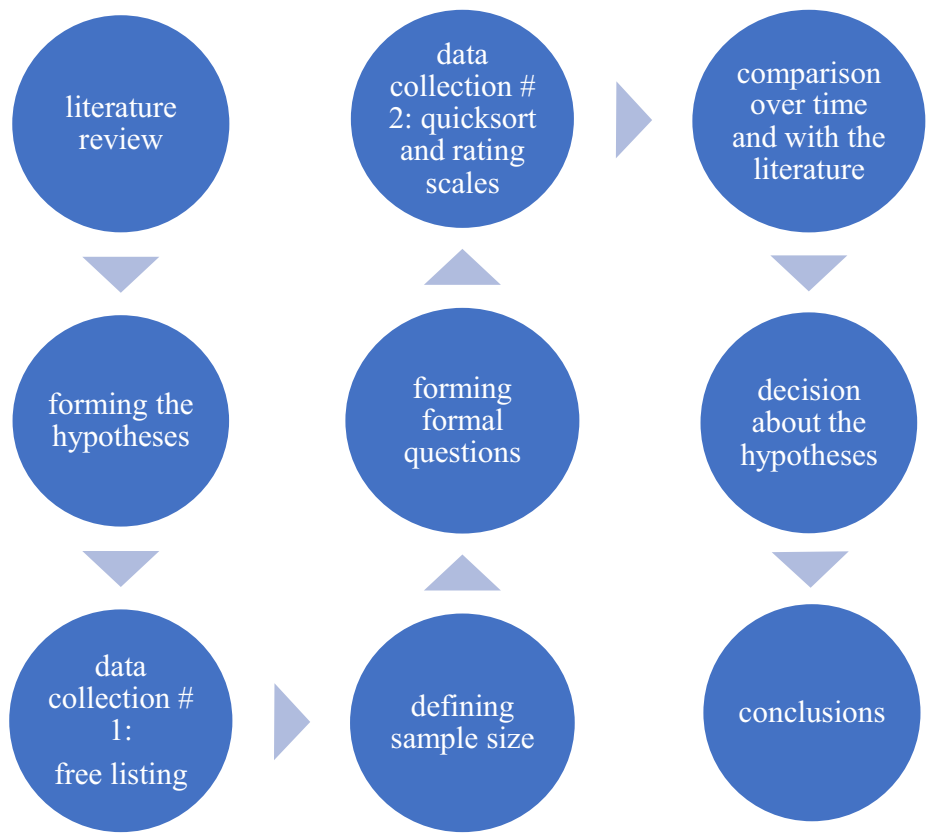

Fig. 2. Flow chart of the research

Source: own compilation 
the causal interpretations of poverty were examined using the same methodology in both 2011 and 2019 (for details refer to Siposné Nándori 2016).

The methodology of systematic data collection was developed in the 1980s in the United States by anthropologist Susan C. Weller and mathematician A. Kimball Romney. This method helps researchers in the field of social sciences collect more useful data through interviews and questionnaires. Increased understanding of experimental and observational data requires systematic observation, classification, analysis, and evaluation. Systematic and structured methods of carrying out interviews help reach this goal (Weller and Romney 1988).

Methods of systematic data collection which, for example, include asking the same set of questions of each participant, decrease the sample size required when researching subjects related to social science in a revolutionary way, while ensuring the results remain highly reliable. This is made possible by taking into consideration the cultural competence of members of society when defining the sample size. The number of interviewees required to get reliable answers can be determined using consensus theory, which can be applied to research questions when researchers do not have a priori knowledge of the answers to the questions which are to be asked. Through evaluation of the cultural competence of the participants, researchers can, in cases like this, discover the 'culturally correct' answers to the questions they formulated. Cultural competence of the participants is the probability that they know the answer to a given question, making the reconstruction of the 'culturally relevant' answers to a specific question possible (Romney et al. 1986). It is assumed that the similarities between the answers of any two participants are a sign of the extent to which each is correlated with the truth, and the extent to which they are the culturally correct answers in this case (Nunally 1978). Consensus theory could be applied in both years in which the research was carried out, as all three required assumptions were achieved:

- The average level of competence of the participants based on free listing was high enough $(<0.7)$,

- the participants were asked separately, and

- each question dealt with the same set of items (Siposné Nándori 2021).

Primary data collection aimed to find out what the individuals believed to be the main causes of poverty. To find the answer to this question, after creating an emic list of reasons for poverty in the initial interviews, the method of quicksort was used in the second phase of research. This is a rank-order method. Names of causes were written on cards which were randomized. A card was then selected to serve as an anchoring standard. All cards were then compared to the standard and were divided into two groups: the cards containing items which are among the causes of poverty more often than the standard card, and those which were the causes of poverty less often than the standard. This process was repeated for each pile until all items were ranked. This method shortens the task of ranking and is appropriate for ranking items according to the frequency with which they are considered to be the causes of poverty (Weller and Romney 1988; Siposné Nándori 2021).

Interviews were conducted during the spring of 2011, in March and April to be exact, and between July and December of 2019. Table 1 summarizes the main facts about the two collections of data. Participants were selected using multi-stage sampling with stratification wherein the sample size from each type of location is in line with the rate of the population in total. Of the towns and cities which were involved (refer to Table 2), Miskolc and Sárospatak are 
Table 1. Sample decomposition based on the distribution of the population of Borsod-Abaúj-Zemplén County, Hungary

\begin{tabular}{|c|c|c|c|c|c|c|}
\hline & \multicolumn{3}{|c|}{2011} & \multicolumn{3}{|c|}{2019} \\
\hline & Population & $\begin{array}{l}\text { Sample size for } \\
\text { free listing }\end{array}$ & $\begin{array}{l}\text { Sample size for } \\
\text { formal interviews }\end{array}$ & $\begin{array}{l}\text { Population } \\
\text { (2018) }\end{array}$ & $\begin{array}{l}\text { Sample size for } \\
\text { free listing }\end{array}$ & $\begin{array}{l}\text { Sample size for } \\
\text { formal interviews }\end{array}$ \\
\hline Town with county rank & 167,754 & 7 & 5 & 155,650 & 10 & 4 \\
\hline Other towns & 234,049 & 10 & 6 & 224,770 & 14 & 7 \\
\hline Communities & 284,463 & 13 & 8 & 267,796 & 17 & 8 \\
\hline Total & 686,266 & 30 & 19 & 648,216 & 41 & 19 \\
\hline Number of items elicited by free listing & \multicolumn{3}{|c|}{52} & \multicolumn{3}{|c|}{45} \\
\hline Average level of competence & \multicolumn{3}{|c|}{0.7} & \multicolumn{3}{|c|}{0.7} \\
\hline $\begin{array}{l}\text { Number of items included for formal } \\
\text { interviews }\end{array}$ & \multicolumn{3}{|c|}{17} & \multicolumn{3}{|c|}{21} \\
\hline $\begin{array}{l}\text { Number of potential causes of poverty } \\
\text { for formal interviews }\end{array}$ & \multicolumn{3}{|c|}{12} & \multicolumn{3}{|c|}{9} \\
\hline $\begin{array}{l}\text { Number of potential consequences of } \\
\text { poverty for formal interviews }\end{array}$ & \multicolumn{3}{|c|}{11} & \multicolumn{3}{|c|}{10} \\
\hline
\end{tabular}

Source: own compilation based on HCSO data. 
Table 2. Sample decomposition and the rate of Roma

\begin{tabular}{|c|c|c|c|}
\hline Settlement & Sample size & Rate of the Roma in 2011 & Step of data collection \\
\hline Miskolc & 10 & 3.24 & \multirow[t]{6}{*}{ Free listing } \\
\hline Ózd & \multirow[t]{2}{*}{14} & 11.00 & \\
\hline Felsőzsolca & & 11.81 & \\
\hline Tiszalúc & \multirow[t]{3}{*}{17} & 8.80 & \\
\hline Ároktő & & 26.43 & \\
\hline Bükkaranyos & & 3.59 & \\
\hline Miskolc & 4 & 3.24 & \multirow[t]{4}{*}{ Formal interviews } \\
\hline Sárospatak & 7 & 2.95 & \\
\hline Bogács & \multirow[t]{2}{*}{8} & 19.16 & \\
\hline Alacska & & 0.00 & \\
\hline Borsod-Abaúj-Zemplén County & - & 9.74 & - \\
\hline
\end{tabular}

Source: own compilation based on HCSO data.

considered relatively developed within the county not only in economic terms, but also in terms of the potential for social innovation (Nagy and Tóth 2019). Regions including Ózd, Ároktő and Bogács, however, are underdeveloped and lack the potential for social innovation. Selecting participants from both relatively developed and underdeveloped areas ensures that wealthier and poorer interviewees are included in this collection of data.

Due to racism directed at the Roma in Hungary, as described above, inclusion of Romani people was also an objective. Because of the lack of consensus regarding who is in fact Roma and who is not, I had no information about the ethnic minority identity of the participants. Some of the selected towns and villages (such as Ózd, Felsőzsolca, Ároktö, and Alacska), however, have higher rates of Roma inhabitants than the county average (Table 2), which effectively ensures that Romani people can also be found among the interviewees.

Following the phase of data collection, results were compared to those described by the relevant literature. Pearson's correlation analysis was used to highlight significant relationships among the causes of poverty, the items related to poverty and the consequences of poverty.

\section{RESULTS}

In 2011, twelve main reasons for poverty were mentioned by the interviewees, while in 2019 only nine causes of poverty were identified. Six items were mentioned in both years. The two primary reasons were 'unemployment' and a 'low willingness to work', and these remained unchanged in both years. They both refer to disadvantages in the labor market. 'A low level of education' and 'low level of income' were ranked between $3^{\text {rd }}$ and $5^{\text {th }}$ during both years. 'Poor health' and 'political/economic causes', also listed in both years, but gained more importance during the 
most recently examined period of time. 'Poor health' rose from $11^{\text {th }}$ place to $6^{\text {th }}$ place, while unfavorable circumstances (such as economic and political problems) rose from $10^{\text {th }}$ place to $7^{\text {th }}$. Some items, such as 'addiction' and 'personal tragedy' (referring to divorce or the death of a relative or friend), 'debt', 'large family', 'inflation', and 'disadvantaged family' were mentioned only in 2011. Others like 'hopelessness', 'isolation', or 'through their own fault' were mentioned only in 2019 (see Fig. 3).

In 2011, 'having a large family' was mentioned as a reason for poverty, but it was not identified as such in 2019. The disappearance of this reason for poverty by 2019 is probably due to the fact that the Hungarian government re-defined its family policy in 2019 and introduced many kinds of child-care benefits (family allowances, family tax allowances, housing subsidies) (Sági et al. 2018), many of which are aimed at parents with three or more children.

Certain causes of poverty mentioned by the participants can be grouped as structural, individual, or fatal causes. Structural causes of poverty are economic and political problems, as well as inflation, while researchers who emphasize individual factors point to factors like alcoholism, substance abuse or the lack of an adequate work ethic (Timmer et al. 1994; Magnet 1993; Main 1998). In the case of other poverty related items such as 'a low level of income', 'hopelessness', 'low level of education', 'unemployment', 'debt', or 'isolation', there can be ambiguities as to whether they are structural, individual, or fatal, therefore they are excluded from this part of the analysis.

In 2011, two reasons mentioned by the interviewees could be considered as structural. 'Inflation' can be an economic cause, but it was mentioned separately, therefore it is listed separately. Additionally, informants mentioned two individual and two fatal causes of poverty. The average scores of the items highlight the fact that individual causes have the lowest score (5.7, while the comparable score is 11 for structural, and 10 for fatal causes); therefore they are the most common subjective reasons of poverty. In 2019, participants identified one structural, one fatal and two individual causes of poverty (refer to Table 3).

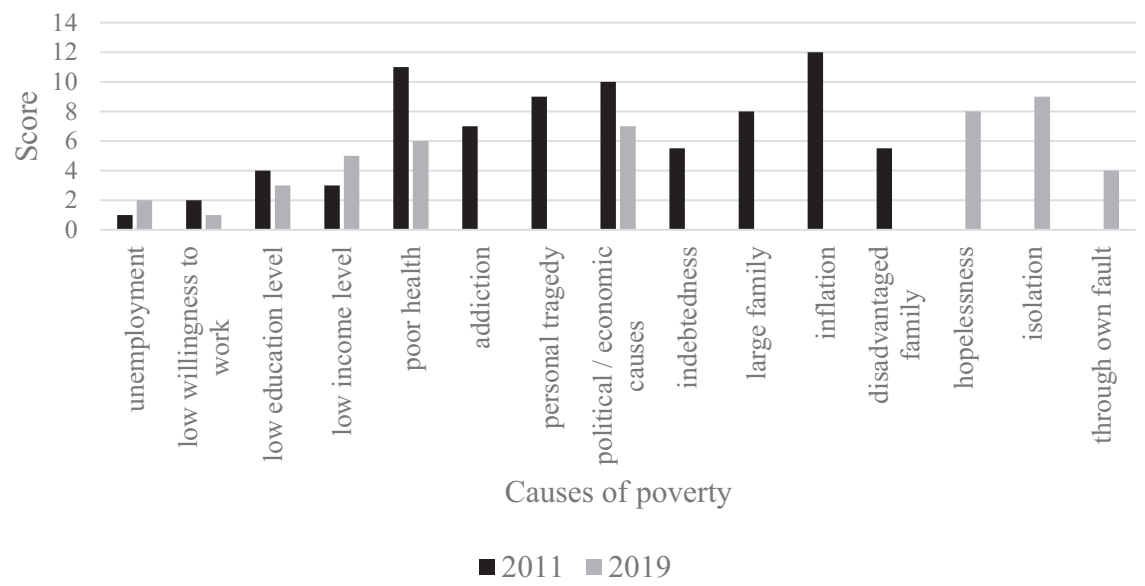

Fig. 3. Subjective reasons for poverty in 2011 and 2019. Score: 1 indicates items most often reasons for poverty

Source: own compilation 
Table 3. Main groups of the causes of poverty

\begin{tabular}{|l|c|c|c|c|}
\hline $\begin{array}{l}\text { Causes of } \\
\text { poverty }\end{array}$ & $\mathbf{2 0 1 1}$ & $\begin{array}{c}\text { Average score based } \\
\text { on free listing }\end{array}$ & $\mathbf{2 0 1 9}$ & $\begin{array}{c}\text { Average score based } \\
\text { on free listing }\end{array}$ \\
\hline Structural & $\begin{array}{c}\text { political/economic } \\
\text { causes inflation }\end{array}$ & 11 & $\begin{array}{c}\text { political/ } \\
\text { economic causes }\end{array}$ & 5 \\
\hline Individual & $\begin{array}{c}\text { low willingness to work } \\
\text { addiction } \\
\text { large family }\end{array}$ & 5.7 & $\begin{array}{c}\text { low willingness } \\
\text { to work } \\
\text { through own } \\
\text { fault }\end{array}$ & 2.5 \\
\hline Fatal & $\begin{array}{c}\text { poor health } \\
\text { personal tragedy }\end{array}$ & 10 & poor health & 6 \\
\hline
\end{tabular}

Source: own compilation.

Table 4. Comparison of structural and individual attributions for poverty based on quicksort results

\begin{tabular}{|c|c|c|c|c|}
\hline \multirow[b]{2}{*}{ Year } & \multirow[b]{2}{*}{ F (sig) } & \multirow[b]{2}{*}{ t (sig) } & \multicolumn{2}{|c|}{ Mean } \\
\hline & & & structural & individual \\
\hline 2011 & $0.788(0.377)$ & $4.302(0.000)$ & 8.84 & 5.88 \\
\hline 2019 & $0.014(0.906)$ & $3.529(0.001)$ & 6.26 & 3.74 \\
\hline
\end{tabular}

Source: own compilation.

The comparison of average scores of structural and individual causes with a test implies that the average scores of individualistic attributions of poverty are significantly different to the structural explanations for poverty in both surveys. The average scores highlight that individual attributions of poverty are perceived to be more important than structural ones (Table 4).

Categories like 'addiction', 'low willingness to work', 'through own fault', or 'having a large family' are the projections of the notion of the so-called 'undeserving poor' which describes people who are their own worst enemies. Szalai (2006) differentiates between two main cases of this undeserving nature of people in poverty: 'having a large family' and 'a low willingness to work'. Szalai goes on to argue that even though having many children, a good planning of the household budget can contribute sufficient resources for the family to live on. As for 'a low willingness to work', a vast body of literature argues that if an individual really wants to work, he or she can always find some kind of a job.

\section{SUMMARY}

The hypothesis according to which the main subjective causes of poverty in Borsod-AbaújZemplén County, Hungary, are structural was rejected. Support for explanations which blame the individual (such as a low willingness to work, addiction, crime or having a large family) are 
stronger than support for explanations which blame structural conditions. The poor are often seen by the public as being themselves responsible for their vulnerable situation.

It is clear that in Hungary there is a discrepancy between the public perception of poverty and the idea of a welfare system which is considered to be generous, and which includes various types of public aid for a wide range of recipients. This finding is in line with the findings of van Oorschot and Halman (2000) who concluded that there was no direct relation between how the members of society perceive poverty and the ways in which welfare policies are designed in Europe. They argue that the lack of a relationship between attributions of poverty and the welfare state may have several reasons. The formation of welfare programs can be affected by other cultural beliefs such as attitudes regarding income inequality, work ethic, or religious feelings. Besides, political or economic factors may have a more significant influence on the welfare system than cultural values. It is also possible that cultural values used to have a significant effect on welfare policies, however, they have lost their importance by now as a result of welfare policies becoming too complex and abstract to reflect public perceptions of poverty.

High support for the individualistic explanations of poverty in the Hungarian county in the focus of this study can also be affected by anti-Roma stereotypes including the idea that Roma people have a low willingness to work, have more children than the majority to ensure a source of income from the government (called 'strategic children') (Durst 2001), are dependent on the welfare system, often commit crimes and do not respect legal and social norms (Csepeli and Simon 2004; Babourkova 2016). These stereotypes coincide with individualistic attributions for poverty (such as addiction, a low willingness to work, or having a large family). Only further research can answer the question as to whether Romani people living in poverty are judged to be responsible for their situation as a result of anti-Roma stereotypes. Beside asking questions about perceptions of poverty, further research should focus on the ethnicity of the participants and on their attitudes towards Roma people. Anti-Roma stereotypes could be deconstructed by sensitization of the majority population. Increased knowledge of Roma history and culture would be needed both amongst the general public and political decision-makers to help them realize that the Roma group is not homogenous, and to stop stereotyping them. This can, in the long run, modify the attributions of poverty as well.

The fact that the public often identifies individualistic explanations of poverty has remarkable implications for the welfare system. Policies aimed to reduce poverty should focus more on the individualistic circumstances of poverty when pursuing the most effective measures of reducing and alleviating poverty. The category of the 'undeserving poor' draws attention to the necessity of considering the degree of the faults of the applicants when applying for welfare programs. Welfare policies should make sure only the faultless poor (like seniors with low pensions who keep their homes tidy, or single mothers with low earnings whose children are neat and regularly attend school) can count on unconditional support from the state and from local municipalities (Szalai 2006).

An obvious limitation of this study is that it is restricted to just one county of Hungary, raising the question as to what extent its findings can be generalized to the country as a whole. Extension of the scope of research to more counties of Hungary would enable spatial comparison revealing regional differences.

The recent COVID-19 pandemic may have affected public perceptions of poverty. Kluegel and Smith (1986) argued that structural beliefs might temporarily become dominant during times of unusual social and/or economic strain. Due to the remarkable social and economic 
effects of the recent pandemic, structural beliefs may have gained strength since the data collection was carried out in 2019. Further research should reveal whether the current pandemic changes related values of the adult population and therefore the subjective interpretations of poverty.

\section{REFERENCES}

Babourkova, R. (2016). Plovdiv: (De-)racialising electricity access? Entanglements of the material and the discursive. In: Luque-Ayala, A. and Silver, J. (Eds.) Energy, power and protest on the urban grid: geographies of the electric city. Routledge, London, pp. 45-63.

Bakos, I. (2006). Causes and regional impacts of the crisis of metallurgy in the Borsod industrial region. European Integration Studies, 5(1): 15-29.

Barta, G., Czirfusz, M., and Kukely, G. (2008). Re-industrialization in the world and in Hungary. European Spatial Research and Policy, 15(2): 5-27.

Blažek, J. and Netrdová, P. (2011). Regional unemployment impacts of the global financial crisis in the new member states of the EU in Central and Eastern Europe. European Urban and Regional Studies, 19(1): 42-61, http://dx.doi.org/10.1177/0969776411428650.

Bullock, H.E. (1999). Attributions for poverty: a comparison of middle-class and welfare recipient attitudes. Journal of Applied Social Psychology, 29(10): 2059-2082.

Cheal, D.J. (1979). Hegemony, ideology and contradictory consciousness. The Sociological Quarterly, 20(1): 109-117.

Coughlin, R.M. (1980). Ideology, public opinion and welfare policy; attitudes towards taxes and spending in industrial societies, Institute of international studies. Research series $n r$. 42. University of California, Berkeley.

Csepeli, Gy. and Simon, D. (2004). Construction of Roma identity in eastern and central Europe: perception and self-identification. Journal of Ethnic and Migration Studies, 30(1): 129-150, https://doi. org/10.1080/1369183032000170204.

Durst, J. (2001). „Nekem ez az élet, a gyerekek”. Gyermekvállalási szokások változása egy kisfalusi cigány közösségben. ("For me, my life is my children". Childbearing habits in a small village gypsy community). Sz vég, 6(22): 71-92.

Feagin, J.R. (1975). Subordinating poor persons: welfare and American beliefs. Prentice-Hall. Englewood Cliffs.

Feather, N.T. (1974). Explanations of poverty in Australian and American samples: the person, society, or both?. Australian Journal of Psychology, 26(3): 199-216.

Free, L. and Cantril, H. (1967). The political beliefs of Americans: a study of public opinion. Rutgers University Press, New Brunswick, NJ.

Furnham, A. (1982). Why are the poor with us? Explanation for poverty in Britain. Journal of Adolescence, 5: 135-147.

G Fekete, É., Péter, Zs., Siposné Nándori, E., Lipták, K., and Hegyi-Kéri, Á. (2013). Területi politikák és stratégiák, Miskolci Egyetem Gazdaságtudományi Kar, Miskolc http://www.tankonyvtar.hu/hu/ tartalom/tamop412A/2011-0046_03_terpol/ (Accessed: 22 October 2017).

Grábics, Á. (Ed.) (2012). Észak-Magyarország megyéinek gazdasági-társadalmi helyzete, 2010. (Socio-economic position of the Counties of Northern Hungary). Központi Statisztikai Hivatal, Budapest. 
Habibov, N. (2011). Public beliefs regarding the causes of poverty during transition: evidence from the Caucasus, Central Asia, Russia, and Ukraine. International Journal of Sociology and Social Policy, 31: 53-74, https://doi.org/10.1108/01443331111104805.

Habibov, N., Cheung, A., Auchynnikava, A., and Fan, L. (2017). Explaining support for structural attribution of poverty in post-communist countries: multilevel analysis of repeated cross-sectional data. Journal of Sociology and Social Welfare, 44(3): 173-197.

Harper, D.J. (1996). Accounting for poverty: from attribution to discourse. Journal of Community \& Applied Social Psychology, 6: 249-265.

Hartz, Louis (1955). The liberal tradition in America: An interpretation of American political thought since the revolution. Harcourt Brace and Co., New York.

Hegyi-Kéri, Á. and Horváth, K. (2017). Vándorlási helyzetkép 2016-ban egy Borsod-Abaúj-Zemplén megyei településröl. (Migration situation in 2016 from a settlement in Borsod-Abaúj-Zemplén county). Tér Társad, 31(4): 214-230.

Hughes, M. and Tuch, S. (2000). How beliefs about poverty affect racial policy attitudes. In: Sears, D., Sidanius, J., and Bobo, L. (Eds.) Racialized politics-the debate about racism in America. University of Chicago Press, Chicago, pp. 165-190.

Hunt, M. (1996). The individual, society, or both? A comparison of Black, Latino and White beliefs about the causes of poverty. Social Forces, 75: 293-322.

Hunt, M. and Bullock, H.E. (2016). Ideologies and beliefs about poverty. In: Brady, D. and Burton, L.M. (Eds.) The oxford handbook of the social science of poverty. Oxford University Press, New York, pp. 93116.

Index. (2006) Lányai előtt verték halálra a gázolót. Index.hu October 16 2006. Accessed: 21 July 2020.

Jordan, B. (1996). A theory of poverty and social exclusion. Polity Press, Cambridge.

Kainu, M. and Niemelä, M. (2014). Attributions for poverty in post-socialist countries, http://muuankarski. github.io/attributions/article2013.pdf (Accessed: 1 December 2020).

Kallio, J. and Niemelä. (2014). Who Blames the Poor? Multilevel evidence of support for and determinants of individualistic explanations of poverty in Europe. European Societies, 16(1): 112-135, https://doi.org/ 10.1080/14616696.2013.787435.

Keller, J., Kovács, K., Rácz, K., Swain, N., and Váradi, M. (2016). Workfare schemes as a tool for preventing the further impoverishment of the rural poor. Eastern European Country's, 22(1): 5-26, https://doi.org/ 10.1515/eec-2016-0001.

Kimmelman, M. (2008). In Hungary, Rome get art show, not a hug. The New York Times, Available via DIALOG https://www.nytimes.com/2008/02/07/arts/07iht-06roma.9817698.html or subordinate document (Accessed: 21 July 2020).

Kluegel, J., Mason, D., and Wegener, B. (Eds.) (1995). Social justice and political change: public opinion in capitalist and post-communist states. De Gruyter, New York.

Kluegel, J.R. and Smith, E.R. (1981). Beliefs about stratification. Annual Review of Sociology, 7: 29-56.

Kluegel, J.R. and Smith, E.R. (1986). Beliefs about inequality: Americans' views of what is and what ought to be (Social institutions and social change). Aldine de Gruyter.

Kósa, K., Daragó, L., and Ádáy, R. (2009). Environmental survey of segregated habitats of Roma in Hungary: a way to be empowering and reliable in minority research. European Journal of Public Health, 21(1): 463-468, https://doi.org/10.1093/eurpub/ckp097.

Kreidl, M. (1998). Changes in the perception of poverty and wealth: Czech Republic between 1991-1995. Czech Sociological Review, 6: 73-97, https://doi.org/10.13060/00380288.1998.34.11.10. 
Kreidl, M. (2000). Perceptions of poverty and wealth in western and post-communist countries. Social Justice Research, 13: 151-176, https://doi.org/10.1023/A:1007597807110.

Lee, B., Jones, S.H., and Lewis, D.W. (1990). Public beliefs about the causes of homelessness. Social Forces, 69(1): 253-265.

Lepianka, D., Oorschot, W., and Gelissen, J. (2009). Popular explanations of poverty: a critical discussion of empirical research. Journal of Social Policy, 38(3): 421-438, https://doi.org/10.1017/ S0047279409003092.

Magnet, M. (1993). The dream and the nightmare: the sixties' legacy to the underclass. William Morrow and Company, New York.

Main, T. (1998). How to think about homelessness: balancing structural and individual causes. Journal of Social Distress and the Homeless, 7(1): 41-54, https://doi.org/10.1023/A:1022966631533.

Marquis, L. (2020). Lay explanations for poverty: a multilevel analysis of European public opinion (1976 2014). In: Careja, R., Emmenegger, P., and Giger, N. (Eds.) The European social model under pressure. Springer VS, Wiesbaden, pp. 253-275, https://doi.org/10.1007/978-3-658-27043-8_15.

Masseria, C., Mladovsky, P., and Hernández-Quevedo, C. (2010). The socio-economic determinants of the health status of Roma in comparison with non-Roma in Bulgaria, Hungary and Romania. European Journal of Public Health, 20(5): 549-554, https://doi.org/10.1093/eurpub/ckq102.

Mau, S. (2003). The moral economy of welfare states. Britain and Germany compared. Routledge, London.

Merolla, D.M., Hunt, M.O., and Serpe, R.T. (2011). Concentrated disadvantage and beliefs about the causes of poverty: a multi-level analysis. Sociological Perspectives, 54(2): 205-228.

Nagy, Z. and Tóth, G. (2019). A társadalmi innovációs potenciál mérési lehetőségei Borsod-Abaúj-Zemplén példáján. (Possibilities of measuring social innovation potential in the example of Borsod-AbaújZemplén county). Émo Strat Füz, 16(2): 97-109.

Niemelä, M. (2008). Perceptions of the causes of poverty in Finland. Acta Sociologica, 51(1), https://doi.org/ $10.1177 / 0001699307086816$.

Nunally, J.C. (1978). Psychometric theory. McGraw-Hill, New York.

Open Society Institute. (2007). Equal access to quality education for Roma, Hungary. EU Monitoring and Advocacy Program (EU MAP), Available via DIALOG https://www.opensocietyfoundations.org/ uploads/d8384d1d-a0dd-44c4-9613-f20d193e8a86/equal_20071218.pdf or subordinate document (Accessed: 20 April 2007).

Parkin, F. (1971). Class inequality and the political order. Praeger, New York.

Pfau-Effinger, B. (2005). Culture and welfare state policies: reflections on a complex interrelation. Journal of Social Policy, 34(1): 3-20, https://doi.org/10.1017/S0047279404008232.

Romney, A.K., Weller, S.C., and Batchelder, W.H. (1986). Culture as consensus: a theory of culture and informant accuracy. American Anthropologist, New Series, 88: 313-338.

Sági, J., Lentner, Cs., and Tatay, T. (2018). Family allowance issues. Hungary in comparison to other countries. Civic Review, 14: 290-301, Special Issue https://doi.org/10.24307/psz.2018.0419.

Simmel, G. (1908). Soziologie: Untersuchungen ueber die Formen der Vergesellschaftung. Dunker und Humblodt, Leipzig.

Siposné Nándori, E. (2016). How did subjective well-being change in Hungary due to the economic crisis?. Social Indicators Research, 126(1): 241-256, https://doi.org/10.1007/s11205-015-0878-9.

Siposné Nándori, E. (2021). Individualism or structuralism-differences in the public perception of poverty between the United States and east-central Europe. J Pov, accepted https://doi.org/10.1080/10875549. 2021.1910892. 
Smith, K.B. and Stone, L.H. (1989). Rags, riches and bootstraps. Beliefs about the causes of wealth and poverty. The Sociological Quarterly, 30(1): 93-107, https://doi.org/10.1111/j.1533-8525.1989.tb01513.x.

Szalai, J. (2006). Poverty and the traps of postcommunist welfare reforms in Hungary: the new challenges of EU-accession. Revija za socijalnu politiku, 13(3-4): 309-333, https://doi.org/10.3935/rsp.v13i3.644.

Taylor-Gooby, P. (1985). Public opinion, ideology and state welfare. Routledge and Kegan Paul, London.

Taylor-Gooby, P. and Svallfors, S. (Eds.) (1999). The end of the welfare state? Responses to state retrenchment. Routledge and Kegan Paul, London.

Timmer, D.A., Eitzen, D.S., and Talley, K.D. (1994). Paths to homelessness: extreme poverty and the urban housing crisis. Westview Press, Boulder, CO.

van Oorschot, W. and Halman, L. (2000). Blame or Fate, Individual or Social. An international comparison of popular explanations of poverty. European Society, 2(1): 1-28, https://doi.org/10.1080/ 146166900360701.

Verwiebe, R. and Wegener, B. (2000). Social inequality and the perceived income justice gap. Social Justice Research, 13: 123-149, https://doi.org/10.1023/A:1007545823040.

Weller, S.C. (2007). Cultural consensus theory: applications and frequently asked questions. Field Methods, 19: 339-368, https://doi.org/10.1177/1525822X07303502.

Weller, S.C. and Romney, A.K. (1988). Systematic data collection. Qualitative research methods, Vol. 10. Sage Publications, Newbury Park.

Williamson, J.B. (1974). Beliefs about the motivation of poor persons and attitudes toward poverty policy. Social Problems, 21: 634-648.

Wilson, G. (1996). Towards a revised framework for examining beliefs about the causes of poverty. The Sociological Quarterly, 37(3): 413-428, https://doi.org/10.1111/j.1533-8525.1996.tb00746.x.

Zucker, G.S. and Weiner, B. (1993). Conservatism and perceptions of poverty: an attributional analysis. Journal of Applied Social Psychology, 23(12): 925-943, https://doi.org/10.1111/j.1559-1816.1993. tb01014.x.

Open Access. This is an open-access article distributed under the terms of the Creative Commons Attribution 4.0 International License (https://creativecommons.org/licenses/by/4.0/), which permits unrestricted use, distribution, and reproduction in any medium, provided the original author and source are credited, a link to the CC License is provided, and changes - if any - are indicated. (SID_1) 